\title{
DOI:10.38136/jgon.836649
}

\section{Risk Factors For Stress, Urge, and Mixed Urinary Incontinence}

\section{Stres, Urge ve Mikst Tıp Üriner Inkontinans Risk Faktörleri}

\author{
Gizem BEKTAȘ \\ Melike DOĞANAY ${ }^{2}$ \\ Burak AKSELIM \\ Mahmut Kuntay KOKANALI ${ }^{2}$ \\ Kadriye Nilay ÖZCAN ${ }^{2}$ \\ Sabri CAVKAYTAR ${ }^{3}$
}

(1) Orcid ID: 0000-0002-7527-2110

(1) Orcid ID: 0000-0002-2603-1812

(1) Orcid ID: 0000-0003-1558-0899

(1) Orcid ID: 0000-0002-0760-446X

(1) Orcid ID: 0000-0002-5270-5630

(1) Orcid ID: 0000-0003-1584-8568

\author{
${ }^{1}$ Gürgan Clinic Women's Health and IVF Center, Ankara,Turkey \\ ${ }^{2}$ Dr. Zekai Tahir Burak Woman's Health Education and Research Hospital, Department of Obstetrics and Gynecology, \\ Ankara, Turkey \\ ${ }^{3}$ Bahceci Health Group, Umut IVF Center, İstanbul, Turkey
}

\section{Öz}

Amaç: Üriner inkontinas tipleri ile ilişkili risk faktörlerinin belirlenmesi bu çalışmada amaçlanmıştır.

Gereç ve Yöntemler: Bu kesitsel çalışma Eylül 2013 ile Temmuz 2014 tarihleri ara-sında yapılmıştır. Çalışmaya 1459 hasta katılmıştır. Bu hastalardan 958 inde idrar kaçırıyorken, 501 i idrar kaçırmıyordu. Üriner inkontinans tanısında ICIQ-SF (Inter-national Consultation on Incontinence Questionnaire Short Form)'un Türkçe versiyonu ile ürojinekolojik ve pelvik muayene kullanıldı. Hastaların ayrıntııı tıbbi öyküleri alındı. Kategorik değişkenler Pearson's Ki-kare testi kullanılarak değerlendirildi. Sürekli değişkenleri analiz etmek için Tek Yönlü Varyans Analizi ve Kruskall-Wallis testleri kullanılmıştır. İstatistiksel olarak anlamlı üriner inkontinans ile ilişkili risk faktörlerini belirlemek için Multiple lojistik regresyon analizi kullanılmıştı.

Bulgular: Hikayesinde $>4000$ gr doğum öyküsü olması, erken menarş, menapoz, konstipasyon, kahve tüketimi, astım, lumbal disk hernisi, aile öyküsü ve tekrarlayan üriner enfeksiyon tüm üriner inkontinans tipleri ile ilişkili bulundu. Evde doğum öy-küsü, stres ve urge inkontinans açısından artmış risk faktörüdür. Sistosel ve rektosel ise hem stres hem de mikst tip üriner inkontinans için artmış risk faktörüdür. Hormon replasman tedavisi alan ve cuff prolapsusu olan hastalarda urge üriner inkontinans riskinin arttığı gösterilmiştir. Yüksek beden kitle indeksi ise mikst tip üriner inkontinans için spesifik risk faktörü olarak gösterildi.

Sonuç: Risk faktörlerinin ve yüksek riskli kadınların belirlenmesi, üriner inkontinans için önleyici tıbbi yaklaşımların geliştirilmesi için çok önemlidir.

Anahtar kelimeler: Üriner inkontinans, stres üriner inkontinans, urge üriner inkontinans, üriner inkonti-nans risk faktörleri

\section{INTRODUCTION}

Urinary incontinence (UI) effects 250 millon people worldwide (1) . In Turkey, the prevalence of UI ranges from $16.4 \%$ to $49.7 \%$ (2). This range is a result of different women's characteristics and different methods of Ul evaluations (3). UI is also accepted as a health problem in Turkey, which is usually ignored.

\section{ABSTRACT}

Aim: The aim of the study was to determine the risk factors associated with specific subtypes of urinary incontinence (UI).

Materials and Methods: This cross-sectional study was conducted between Sep-tember 2013 and July 2014. There were 1459 patients included in our study. Of these, 958 women were incontinent, and 501 were continent. The Turkish version of the International Consultation on Incontinence Questionnaire Short Form (ICIQ-SF), urogynecologic and pelvic examination were used for UI diagnosis. Patients' detailed medical histories were obtained. Categorical variables were evaluated using Pearson's Chi-squared test. One-way Analysis of Variance and Kruskall-Wallis tests were used to analyze continous variables. Multiple logistic regression analysis was used to obtain statistically significant UI-associated risk factors.

Results: A history of giving birth to a baby weighing $>4000 \mathrm{gr}$, early age at menar-che, menopause, constipation, coffee consumption, asthma, lumbal disc hernia, family history, and recurrent urinary infections were associated with all types of UI. Delivery at home increased the risk of both stress and urge urinary incontinence (SUI and UUI, respectively). Cystocele and rectocele increased the risk of both SUI and mixed urinary incontinence (MUI). The risk of UUI was shown to increase in women who were receiving hormone replacement therapy and who had cuff prolapse. High body mass index was indicated as a specific risk factor for MUI.

Conclusion: Determining risk factors and high risk women is very important for de-velopment of preventative medical approaches for UI.

Keyword: sstress urinary incontinence, urge urinary incontinence, urinary incontinence risk fac-tors, mixed urinary incontinence

$\mathrm{UI}$ is not a life-threatening condition, but the symptoms have a serious effect on women's physical, psychological, and social life. Women delay or refuse the treatment. because of embrassment or the thinking that $\mathrm{UI}$ is a normal process related to aging and vaginal delivery. Most women have UI, but few seek treatment (4). In already developed and developing countries 
many women have the risk of Ul. Although there are a lot of studies about the potential risk factors for UI, there are only a few studies describing the risk factors for different types of UI (5-7). Therefore, in our study we aimed to identify specific risk factors for different types of UI.

\section{MATERIALS AND METHODS}

This cross-sectional study was conducted in the Urogynecology Department of Zekai Tahir Burak Women's Health Education and Research Hospital from September 2013 to July 2014. Nine hundred and fifty eight women presenting with the complaint of UI were identified as cases, while 501 women who had been admitted to the Gynecology Department with other complaints such as abnormal uterine bleeding, pelvic pain, and vaginal discharge were selected as controls. Pregnant women were excluded from the study. The study was approved by the Ethics Committee of Dr Zekai Tahir Burak Woman's Health Education and Research Hospital.

For the diagnosis and determination of the type of UI, the Turkish version of the International Consultation on Incontinence Questionnaire Short Form (ICIQ-SF), urogynecologic and pelvic examination were used (8). All patients were asked their age, height, weight, the number of gravidity, parity, mode of delivery (vaginal delivery at hospital/ Cesarean section/vaginal delivery at home), macrosomic delivery ( $\geq 4000 \mathrm{~g}$ birth weight), age at menarche, age of first pregnancy, menopausal status, education level, constipation, smoking, daily tea/coffee consumption, chronic illnesses, family history of UI, recurrent urinary infections, and surgical history. Body mass index (BMI) was calculated as weight $(\mathrm{kg}) /(\text { height })^{2}\left(\mathrm{~m}^{2}\right)$. A subject was considered a smoker if she had smoked > one cigarette per day for at least one year. If the patient drank > one cup of coffee or tea daily, she was considered a caffeine consumer. The presence of lumbal disc hernia (LDH) was accepted if it had been shown by magnetic resonance imaging. Patients who were menopausal were questioned about use of hormone replacement therapy (HRT) for at least three months. If a patient had a surgical history, the type(1) of the surgery was determined by the surgery report. Family urinary incontinence was evaluated by the presence of maternal UI. A patient was considered constipated if she had constipation for $>1$ year. A patient who declared two or more episodes of urinary tract infection per year was considered to have recurrent urinary tract infections (9) .
Each patient underwent a standard evaluation in the urogynecology department, including pelvic examination, urinalysis, urine culture, fasting blood glucose level, and cough stress test. A patient who had a urinary tract infection and unregulated blood glucose levels due to diabetes mellitus (DM) was excluded from the study. Pelvic floor defects were examined by the Baden Walker Quantification system. The presence of urine leakage during coughing when the bladder held $300 \mathrm{ml}$ was considered as positive cough stress test. For the patients who had reported urine leakage while walking or moving but whose stress test was negative, the pad test was performed. After 15 minutes of walking and 15 minutes of stair climbing, a patient's pad weight was measured. If the difference before and after exercising was $>2 \mathrm{gr}$, the pad test was evaluated as positive.

Statistical analysis was performed using the Statistical Program for Social Sciences (SPSS, Version 22.0; Chicago, IL, USA). Descriptive values for categorical variables were frequency and percentages, for continous variables with normal distribution mean \pm standard deviation was used, and for continous variables with abnormal distribution median (interquartile range) was used. Categorical variables were evaluated using Pearson's Chi-squared test. One-way analysis of variance (ANOVA) and Bonferroni tests were used to analyze continous variables with normal distribution, and the Kruskall-Wallis test was used for continous variables with abnormal distribution. When there were significant differences between the groups, the chi-squared and Mann-Whitney $U$ tests with a correction of the Bonferroni test were performed. To obtain statistically significant risk factors for urinary incontinence, we also used multiple logistic regression analysis. $P$ values $<0.05$ were regarded as significant.

\section{RESULTS}

There were 1459 patients in our study. Of these, 958 women were incontinent, and 501 women were continent. Of the incontinent women, 476 (49.68\%) women had stress urinary incontinence (SUI), 199 (20.77\%) had urge urinary incontinence (UUI), and $283(29.54 \%)$ had mixed urinary incontinence (MUI). SUI was the most frequent type followed by MUI and UUI.

Table 1 shows the subjects' demographic characteristics. In comparison, the mean age of SUI was significantly lower ( $p$ $<0.001)$. 
Table 1 Demographic characteristics of the groups

\begin{tabular}{|l|l|l|l|l|l|}
\hline & $\begin{array}{l}\text { Control } \\
(\mathbf{n = 5 0 1})\end{array}$ & $\begin{array}{l}\text { SUI } \\
(\mathbf{n = 4 7 6})\end{array}$ & $\begin{array}{l}\text { UUI } \\
(\mathbf{n = 1 9 9 )}\end{array}$ & $\begin{array}{l}\text { MUI } \\
(\mathbf{n = 2 8 3})\end{array}$ & $\mathbf{P}$ \\
\hline Age & $54,1 \pm 6,9$ & $50,0 \pm 8,4$ & $52.3 \pm 11,1$ & $50,8 \pm 9,6$ & $<\mathbf{0 , 0 0 1}$ \\
\hline Education & & & & & \\
None & $80(16)$ & $86(18,1)$ & $52(26,1)$ & $71(25,1)$ & \\
Primary & $320(63,9)$ & $306(64,3)$ & $104(52,3)$ & $169(59,7)$ & \\
Secondary & $33(6,6)$ & $23(4,8)$ & $13(6,5)$ & $16(5,7)$ & $<\mathbf{0 , 0 5}$ \\
High, & $59(11,8)$ & $48(10,1)$ & $20(10,1)$ & $22(7,8)$ & \\
University & $9(1,8)$ & $13(2,7)$ & $10(5)$ & $5(1,8)$ & \\
\hline BMI $\left(\mathrm{kg} / \mathrm{m}^{2}\right)$ & $30.0 \pm 5,0$ & $30,7 \pm 4,6$ & $30,9 \pm 5,0$ & $32,0 \pm 5,1$ & $<\mathbf{0 , 0 0 1}$ \\
\hline Smoking & $92(18,4)$ & $70(14,7)$ & $51(25,6)$ & $57(20,1)$ & $<\mathbf{0 , 0 5}$ \\
\hline & & & & & \\
\hline
\end{tabular}

Values were given as mean \pm standard deviation, number $(\%)$

$\mathrm{p}<0.05$ was considered statistically significant

SUI: stress urinary incontinence, UUI: urge urinary incontinence, MUI: mixed urinary incontinence, BMI: body mass index

All the groups had a mean BMl of $>30 \mathrm{~kg} / \mathrm{m}^{2}$, and all of our subjects were obese. There was no statistically significant difference between the groups' parity and gravidity (Table 2).

Table 2 The effect of independent variables on urinary incontinence (multiple logistic regression analysis)

\begin{tabular}{|c|c|c|c|c|c|c|c|c|c|}
\hline \multirow[t]{2}{*}{ Variables } & \multicolumn{3}{|c|}{ Control $\rightarrow$ SUI } & \multicolumn{3}{|c|}{ Control $\rightarrow$ UUI } & \multicolumn{3}{|c|}{ Control $\rightarrow$ MUI } \\
\hline & $\mathrm{OR}$ & $\% 95 \mathrm{CI}$ & $P$ & OR & $\% 95 \mathrm{CI}$ & $P$ & OR & $\% 95 \mathrm{CI}$ & $P$ \\
\hline BMI & NS & & & NS & & & 1,045 & $1,000-1,092$ & $<0,05$ \\
\hline Macrosomia & 15,145 & $6,135-37,384$ & $<0,001$ & 24,296 & $9,223-64,005$ & $<0,001$ & 16,144 & $6,299-41,378$ & $<0,001$ \\
\hline Age at menarche & 0,626 & $0,531-0,739$ & $<0,001$ & 0,798 & $0,665-0,958$ & $<0,05$ & 0,748 & 0,623-0,899 & $<0,01$ \\
\hline Delivery at home & 3,073 & $1,872-5,046$ & $<0,001$ & 6,484 & $3,744-11,231$ & $<0,001$ & NS & & \\
\hline Menopausal status & 2,872 & $1,632-5,054$ & $<0,001$ & 2,845 & $1,470-5,504$ & $<0,01$ & 2,233 & $1,170-4,263$ & $<0,05$ \\
\hline HRT & NS & & & 16,886 & $1,773-160,80$ & $<0,05$ & NS & & \\
\hline Constipation & 3,253 & $2,094-5,051$ & $<0,001$ & 2,87 & $1,677-4,914$ & $<0,001$ & 2,336 & $1,373-3,976$ & $<0,01$ \\
\hline Coffee consumption & 2,236 & $1,063-4,700$ & $<0,05$ & 2,995 & $1,257-7,134$ & $<0,05$ & 4,372 & $1,976-9,670$ & $<0,001$ \\
\hline Asthma & 3,456 & $1,206-9,905$ & $<0,05$ & 6,209 & $2,151-17,923$ & $<0,001$ & 7,604 & $1,976-9,670$ & $<0,001$ \\
\hline LDH & 9,920 & $4,956-19,858$ & $<0,001$ & 7,895 & $3,752-16,615$ & $<0,001$ & 8,065 & $3,667-17,738$ & $<0,001$ \\
\hline Family history & 7,357 & $4,436-12,200$ & $<0,001$ & 4,658 & $2,541-8,537$ & $<0,001$ & 5,967 & $3,334-10,682$ & $<0,001$ \\
\hline $\begin{array}{l}\text { Recurrent urinary } \\
\text { infections }\end{array}$ & 6,804 & 4,173-11,093 & $<0,001$ & 3,881 & $2,166-6,952$ & $<0,001$ & 6,093 & $3,478-10,675$ & $<0,001$ \\
\hline Cystocele & 1,602 & $1,289-1,992$ & $<0,001$ & NS & & & 1,806 & $1,366-2,389$ & $<0,001$ \\
\hline Rectocele & 1,518 & $1,242-1,857$ & $<0,001$ & NS & & & 1,565 & $1,225-1,999$ & $<0,001$ \\
\hline Cuff Prolapse & NS & & & 2,934 & $1,158-7,432$ & $<0,05$ & NS & & \\
\hline
\end{tabular}

$<0.05$ was considered statistically significant, NS: not significant

SUI: stress urinary incontinence, UUI: urge urinary incontinence, MUI: mixed urinary incontinence,BMI: body mass index,NVD: normal vaginal delivery, HRT:hormone replacement therapy,LDH:lumbal disc hernia, BMI: body mass index

Education level, mode of delivery, first delivery before the age of 24 years, hysterectomy, abdominal, pelvic organ prolapse, and anti-incontinence surgeries, smoking, tea consumption, diabetes mellitus, hypertension, chronic obstructive lung disease, cerebrovascular and neurological diseases, and descensus uteri were not associated with UI. In multiple logistic regression analysis, a history of giving birth to a baby weighing $>4000$ $\mathrm{gr}$, early age at menarche, menopause, chronic constipation, more than one cup of daily coffee consumption, asthma, LDH, family history of UI, and recurrent UTIs were associated with all types of UI. Delivery at home increased the risk of stress and urge UI. (OR: 3.073, $p<0.001$ and OR:6.484 p<0.001, respectively). Cystocele and rectocele increased the risk of SUI and MUI. The risk of UUI increased in women who were HRT users
(OR:16.886, $p<0.05)$ and who had cuff prolapse (OR:2.034, $p$ $<0.05$ ). In the current study, a high body mass index (OR:1.045 $p<0.05)$ appeared to be a specific risk factor for MUI.

\section{DISCUSSION}

Consistent with other literature reports, the most common type of UI was SUI followed by MUI and UUI in our study (9). It was evident that aging appears to be a distinct risk factor for UI (10, 11). However, in our study the mean age of SUI and MUI groups was significantly lower than control and UUI groups. Several older literature studies suggested that the prevalence of SUI may decrease with advancing age because daily activities decrease, and the urge component predominantly masks SUI in elderly women (12).

Previous studies stated obesity was an independent risk factor for Ul. Obese or overweight women have greater increased intrabdominal pressure, therefore pelvic organ prolapse and UI develop more easily $(11,13)$. In this study, BMI was found to be a risk factor for MUI. However, including control groups, all groups had a mean BMl of $30 \mathrm{~kg} / \mathrm{ml}$, and all of the groups were obese; therefore, it is a limitation of the study to say that obesity is a risk factor for urinary incontinence.

Low education level leads to less income; less educated women do not seem to care about their own health as musch as educated ones and do not take precautions for UI (14). We found significantly lower education levesl in UUI and MUI groups but in multiple logistic regression analysis, low education level was not a significant risk factor for UI.

It is generally accepted that smoking causes both a reduction in collagen synthesis (which has anti-estrogenic effects) and a chronic cough, thus contributing to long-term high intra-abdominal pressure. Both of these factors may lead to an increased risk of SUI (11). However, in our study, there was no association with smoking and UI. Smoking may cause loss of muscle tone, sensorineurol problems, and not-yet-identified problems.

As we researched the relationship between $\mathrm{UI}$ and tea/coffee consumption, we found that only consumption of coffee, not tea, increased the risk for all types of UI. There are many conflicting studies investigating the association of caffeine with UI. In the EPINCONT study (Epidemiology of Incontinence in the County of Nord -Trøndelag), a positive correlation with coffee consumption and MUI and negative correlation with SUI was shown (11). $\mathrm{UI}$ is more frequent in parous rather than in nulliparous women $(9,15)$. However, the effect of delivery mode is still unclear. 
Some studies showed that vaginal delivery increased the risk of $U I(16,17)$. In our study, gravidity and parity between the groups were similar and we found that there was no relation between parity, mode of delivery, and UI. On the other hand, delivering a baby weighing $>4000 \mathrm{~g}$ increased the risk of all types of UI; the risk of UUI increased the most. Additionally, there was no information in the literature about the effect of home delivery on UI. In this study, home delivery was found to be an important risk factor for SUI and UUI. This effect was thought to be related to an increase in more damage to the pelvic floor and perineum.

During menopause, lack of estrogen may also cause weakening of the pelvic muscles responsible for bladder control, resulting in urinary incontinence (18). Consistent with this, in our study, menopause increased all the types of UI. We also examined the impact of age at menarche on UI. We found that an early age of menarche increased the risk of all types of UI, and this incremental risk was the highest for SUI. When patients' ages at their first pregnancy were compared, no significant association was observed. In contrast to that, Seshan et al. reported urinary incontinence symptoms to be more serious in women who delivered their first baby at an early age (19).

The impact of HRT use on urinary incontinence is still controversial. There are a few possible mechanisms for this effect. In women using HRT, reduction in the concentrations of paraurethral collagen, an increase in mRNA, which contributes to the synthesis of types $1 \llbracket 3$ collagen, and the incremental activity of matrix metalloproteinase-2 showed an increase in collagen cycling; it appears that estrogen could impair the connective tissue supplying urethral support (20). Additionally, animal studies revealed that estrogen treatment increased the smooth muscle /collagen ratio, vascular density, and contractility of the bladder (20). Parazzini et al. reported that women using HRT were at a mildly high risk of SUI and MUI (16). Grodstein et al. reported that women who were still using HRT were at a high risk for UI (21). In contrast to results described in a review by Cochrane on the treatment of UI with estrogen therapy in menopause, Moehrer et al. reported that estrogen therapy was more effective than a placebo and could even be curative for UI (22). We found that HRT increased the risk of UUI almost 17 times, but there was no association between HRT, stress, and mixed urinary incontinence. However there were just 16 women using HRT in our study, and this small number limited the validity of the effects of HRT on UI.

In a previous study, the risk of UI on women who had undergo- ne hysterectomy was found to be increased, but this increased risk wasn't found in women who were $<60$ years (23). Recently, studies have shown that hysterectomy could be the initial point of pelvic floor symptoms such as urinary incontinence, constipation, and sexual problems (11). In our study, hysterectomy, abdominal, pelvic organ prolapse and anti-incontinence surgeries were evaluated separately, and all types of surgery were not considered risk factors for urinary incontinence.

In our study, asthma and chronic obstructive lung disease were assessed separately, and asthma was found to be a risk factor for all types of UI. In contrast, Horng et al. found that the rate of $\mathrm{UI}$ in the emphysema/chronic obstructive lung disease group was significantly higher than the asthma group (24). Consistent with our study, Barghouti et al. reported that asthma was a risk factor for all types of UI (9). The relationship between DM and UI has been shown in the literature $(9,16)$. In this study, DM was not associated with urinary incontinence.

We found that recurrent tract urinary infections increased the risk of all types of $U I$. There are many studies in which recurrent UTIs were associated with UI $(9,16,17)$. This effect of UTIs has been reported to depend on decreasing pressure of the sphincter and increasing contractions of detrusor muscles (25). It is still unclear whether UTIs are the cause or the result of UI (18). Consistent with Timur-Tashan et al.'s study, our study showed that a family history of UI increased the risk of all types of $\mathrm{UI}$ (26). Altintas et al. reported that LDH increased the risk of MUI (27), and we found that LDH was significantly higher in all our groups of Ul.

Pelvic organ prolapse was evaluated separately, and the presence of cysto-rectocele appeared to be a risk factor for both MUI and SUI, while the presence of cuff prolapse appeared to be related to UUI. Bai et al. determined that the rate of SUI in patients with pelvic organ prolapse and the rate of pelvic organ prolapse in patients with SUI, were both high (28). Long et al. reported that when compared with the control group urinary symptoms such as frequency, urgency, nocturia, and UUI/SUI were significantly higher in the prolapse group (29). Literature studies dealing with this topic are limited; it isn't yet understood whether pelvic organ prolapse accompanies $\mathrm{UI}$, or $\mathrm{UI}$ is formed because of pelvic organ prolapse.

Al Badr et al. reported that constipation as a result of increasing urethral pressure with high intraabdominal pressure and influence on the pelvic support structure increased the risk of $\mathrm{UI}$ (30). Similarly, we determined constipation as a risk factor for all types of UI. 
One potential limitations of this study was that the diagnosis of the type of urinary incontinence was based on anamnestic data. However each patient was questioned and examined by the same gynecologist; that procedure may actually prove to be a strength of the analysis.

In conclusion, urinary incontinence is a common condition that decreases the quality of life for women who suffer from it, and it causes high costs for insurance companies. Determination of Ul risk factors is very important for development of preventative medical approaches.

\section{Acknowledgement: None}

\section{Funding: No}

Conflict of Interest: The authors declare that they have no conflict of interest

\section{REFERENCES}

1. Beji NK, Ozbas A, Aslan E, Bilgic D, Erkan HA. Overview of the social impact of urinary incontinence with a focus on Turkish women. Urologic Nursing. 2010;30(6):327.

2. Filiz TM, Uludag C, Cinar N, Gorpelioglu S, Topsever P. Risk factors for urinary incontinence in Turkish women. A cross-sectional study. Saudi medical journal. 2006;27(11):168892.

3. Dursun P, Dogan NU, Kolusari A, Dogan S, Ugur MG, Komurcu $\mathrm{O}$, et al. Differences in geographical distribution and risk factors for urinary incontinence in Turkey: analysis of 6,473 women. Urologia internationalis. 2013;92(2):209-14.

4. Norton P, Brubaker L. Urinary incontinence in women. The Lancet. 2006;367(9504):57-67.

5. Walker GJ, Gunasekera P. Pelvic organ prolapse and incontinence in developing countries: review of prevalence and risk factors. International urogynecology journal. 2011;22(2):127-35.

6. Chiu A-F, Huang M-H, Wang C-C, Kuo H-C. Prevalence and factors associated with overactive bladder and urinary incontinence in community-dwelling Taiwanese. Tzu Chi Medical Journal. 2012;24(2):56-60.

7. Rortveit G, Hannestad YS, Daltveit AK, Hunskaar S. Ageland Type[Dependent Effects of Parity on Urinary Incontinence: The Norwegian EPINCONT Study. Obstetrics \& Gynecology. 2001;98(6):1004-10.

8. Cetinel B, Ozkan B, Can G. The validation study of
ICIQ-SF Turkish version. Turk J Urol. 2004;30(3):332-8.

9. Barghouti FF, Yasein NA, Jaber RM, Hatamleh LN, Takruri AH. Prevalence and risk factors of urinary incontinence among Jordanian women: impact on their life. Health care for women international. 2013;34(11):1015-23.

10. Cerruto MA, D'Elia C, Aloisi A, Fabrello M, Artibani W. Prevalence, incidence and obstetric factors' impact on female urinary incontinence in Europe: a systematic review. Urologia internationalis. 2012;90(1):1-9.

11. Hannestad YS, Rortveit G, Daltveit AK, Hunskaar S. Are smoking and other lifestyle factors associated with female urinary incontinence? The Norwegian EPINCONT Study. BJOG: An International Journal of Obstetrics \& Gynaecology. 2003;110(3):247-54.

12. Nygaard IE, Heit M. Stress urinary incontinence. Obstetrics \& Gynecology. 2004;104(3):607-20.

13. Hunskaar S. A systematic review of overweight and obesity as risk factors and targets for clinical intervention for urinary incontinence in women. Neurourology and urodynamics. 2008;27(8):749-57.

14. Liu B, Wang L, Huang S-S, Wu Q, Wu D-L. Prevalence and risk factors of urinary incontinence among Chinese women in Shanghai. International journal of clinical and experimental medicine. 2014;7(3):686.

15. Kirss F, Lang K, Toompere K, Veerus P. Prevalence and risk factors of urinary incontinence among Estonian postmenopausal women. Springerplus. 2013;2(1):1-7.

16. Parazzini F, Chiaffarino F, Lavezzari M, Giambanco V. Risk factors for stress, urge or mixed urinary incontinence in Italy. BJOG: An International Journal of Obstetrics \& Gynaecology. 2003;110(10):927-33.

17. Persson J, Wølner-Hanssen P, Rydhstroem H. Obstetric Risk Factors for Stress Urinary Incontinence: A Population[Based Study. Obstetrics \& Gynecology. 2000;96(3):440-5.

18. Rekers $H$, Drogendijk A, Valkenburg $H$, Riphagen F. The menopause, urinary incontinence and other symptoms of the genito-urinary tract. Maturitas. 1992;15(2):101-11.

19. Seshan V, Muliira JK. Self-reported urinary incontinence and factors associated with symptom severity in community dwelling adult women: implications for women's health promotion. BMC women's health. 2013;13(1):1.

20. Townsend MK, Curhan GC, Resnick NM, Grodstein F. Postmenopausal hormone therapy and incident urinary incon- 
tinence in middle-aged women. American journal of obstetrics and gynecology. 2009;200(1):86. e1-. e5.

21. Grodstein F, Lifford K, Resnick NM, Curhan GC. Postmenopausal hormone therapy and risk of developing urinary incontinence. Obstetrics \& Gynecology. 2004;103(2):254-60.

22. Moehrer B, Hextall A, Jackson S. Oestrogens for urinary incontinence in women. The Cochrane Library. 2003.

23. Brown JS, Sawaya G, Thom DH, Grady D. Hysterectomy and urinary incontinence: a systematic review. The Lancet. 2000;356(9229):535-9.

24. Horng SS, Huang N, Wu SI, Fang YT, Chou YJ, Chou $P$. The epidemiology of urinary incontinence and it's influence on quality of life in Taiwanese middlelaged women. Neurourology and urodynamics. 2013;32(4):371-6.

25. Tozun M, Ayranci U, Unsal A. Prevalence of urinary incontinence among women and its impact on quality of life in a semirural area of Western Turkey. Gynecologic and obstetric investigation. 2009;67(4):241-9.

26. Timur-Taşhan S, Beji NK, Aslan E, Yalçin Ö. Determining lower urinary tract symptoms and associated risk factors in young women. International Journal of Gynecology \& Obstetrics. 2012;118(1):27-30.

27. Altintas R, Beytur A, Oguz F, Tasdemir C, Kati B, Cimen $S$, et al. Assessment of urinary incontinence in the wo- men in Eastern Turkey. International urogynecology journal. 2013;24(11):1977-82.

28. Bai S, Jeon M, Kim J, Chung K, Kim S, Park K. Relationship between stress urinary incontinence and pelvic organ prolapse. International urogynecology journal. 2002;13(4):25660.

29. Long CY, Hsu SC, Sun DJ, Chen CC, Tsai EM, Su $\mathrm{JH}$. Abnormal clinical and urodynamic findings in women with severe genitourinary prolapse. Kaohsiung J Med Sci. 2002;18(12):593-7.

30. Al-Badr A, Brasha H, Al-Raddadi R, Noorwali F, Ross $S$. Prevalence of urinary incontinence among Saudi women. International journal of gynaecology and obstetrics: the official organ of the International Federation of Gynaecology and Obstetrics. 2012;117(2):160-3. 